\title{
Representation of "Other" in Russian and German Media Discourse
}

\author{
Marina Milovanova, and Marina Svinkina* \\ Volgograd State University, 400062, Universitetskiy Av., 100, Volgograd, Russia
}

\begin{abstract}
The article is devoted to the opposition "we vs. they" in Russian and German linguistic cultures. Analysis of linguistic means representing this opposition allows identifying the national and cultural specificity of perception of the identified phenomena in non- relative linguistic cultures. It is shown that the most frequently used strategies in the Russian and German media discourse are alteration and empathization. The most popular tactics and communicative turns of the particular strategies of representation of the "other" were exposed in the both media discourses. The discourse and contrastive analysis of Russian and German newspaper texts is used as the research method.
\end{abstract}

\section{Introduction}

In modern society mass media texts are matched by a certain way, become one of the main sources of stereotypes [1]. Analysis of the representation of social reality in both Russia and Germany allows us to note the tendency of the media to manipulate micro-differences [2]. When trying to characterize the "other" in a media discourse, the following three aspects are of main importance: 1. "the other" is an outsider; 2 . he or she differs from us, but we are not enemies; 3 . Relationships with "others" can take different forms: from friendship and love, to polemics and confrontation [3].

In the philosophical sense otherness is the result of a discursive process by which a dominant in-group constructs one or many dominated out-groups by stigmatizing a difference - real or imagined - presented as a negation of identity and thus a motive for potential discrimination. The creation of otherness consists of applying a principle that allows individuals to be classified into two hierarchical groups: them and us. Otherness and identity are two inseparable sides oft he same coin. The Other only exists relative to the Self, and vice versa [4].

The otherness is the way of defining an identity in relation to others. The identity is mainly a product of social, cultural, political and other ways of construction through different approaches. The idea of otherness is representative to sociological analyses of how majority and minority identities are built. The asymmetry in power relationships is central to the construction of otherness $[5,6]$.

\section{Alteration strategy: comparative analysis in the german and in the russian discourse}

The analysis of Russian and German press articles over the period 2016 to 2018 has shown that the otherness can be performed by means of alteration strategy, which refers to the human instincts.

\section{Alteration strategy}

The alteration strategy is intended to compare representatives of "our" group with those who opposes us, shares other values, has a different worldview and at the same time reveals similar features [7]. The alteration strategy results in the use of two tactics: contrasting and distancing.

Contrasting tactic. The contrasting tactic involves the thematisation of the comparison and its explicit expression. To implement this tactic, in the media discourse the communicative turn of drawing a parallel and the communicative turn of hierarchy are used. The analysis of the empiric material has shown that as actual "other" in the media discourses of Russia and Germany are perceived representatives of different generations, non-traditional sexual orientation, disabled people, as well as a separate category of citizens who have a migration background. It is worth noting that perception of their otherness has different types of manifestation.

Let us look at the examples of developing "otherness" in media discourses of both countries.

Turn of drawing a parallel allows to explicate the "otherness" of the described subject. To establish the idea of difference with the goal of self-identification, it is necessary to actualize in the minds of members of the dominant social group certain differentiating schemes, the list of which can vary in different societies.

The language means of implementing the turn of drawing a parallel are:

- cross nominative lexical items, which call the phenomena in the framework of one concept (opposition

\footnotetext{
* Corresponding author: svinkina29@gmail.com
} 
"we vs. they"): молодежь vs. более старшее поколение, поколение наших родителей, старики; старшее поколение vs. миллениаль, поколение Z / уоuth vs. the older generation, the generation of our parents, the elderly; older generation vs. milleniales, generation $Z$; Die Jungen vs. ältere Generation, Senioren, Silberne Reserven, Rentner; люди с традиционной $u$ нетрадиичонной ориентацией, гетеро- $u$ гомосексуаль, сексуальное большинство $u$ меньиинство / people with traditional and nontraditional orientation, heterosexual and homosexual, sexual majority and minority; Hetero -, Bi- und Heterosexuelle, Angehörige sexueller Minderheiten oder Mehrheiten, Menschen mit traditionellen sexuellen Orientierung und LGBT / Hetero -, bi - and heterosexuals, members of sexual minorities or majorities, people with traditional sexual orientation and LGBT people ; здоровые люди vs. инвалиды, лица с ограниченными физическими возможностями, люди с отклонениями, калеки / healthy people vs. disabled people, people with disabilities, cripples; Gesunde oder normale Menschen vs. Behinderten / Healthy or normal people vs. disabled. The name of the comparison object is usually not specific, in the generalized form "we vs. they".

- personal and possessive pronouns, the use of which is reduced to opposition us vs. they, ours vs. their: Против этой идеи выступает старшее поколение с их "советской ностальгией"; Наши дедь вынграли войну, наши отиы строили БАМ, за считанные годы воздвигали города на крайнем севере, покоряли космос. А что оставят после себя ваши? / Against this idea is the older generation with their "Soviet nostalgia"; Our grandfathers won the war, our fathers built the Baikal-Amur Mainline (BAM), in a few years erected cities in the far north, conquered space. And what will leave your relatives behind?

- complex sentences, emphasizing the semantic parallelism, based on comparison: Молодые не могут, старики не хотят / Young can not, old people do not want; Alte wollen Brexit, Junge die EU; Die Welt ist anders - die Jugend auch; Wir Normalen - die Behinderten/

- estimated adjectives with a given semantics of "otherness": Что делать, если в классе оказался «нестандартный» ученик?/ What should be done if there is a "non-standard" student in the classroom?; Besondere Kinder machen besondere Sorgen / Special children disturb special.

- lexical items, indicating different temporal location of objects (antonymicity of time intervals within the opposition "we vs. they"): Разница между моим поколением и поколением моих родителей была намного меньше, чем между мной теперешней и нынешними тридцатилетними / The difference between my generation and the generation of my parents was much less than between me at the present age and current thirty years old people; Die damaligen Kinder verbrachten ihre Freizeit zusammen und spielten gemeinsam auf dem Schulhof. Die Jugend von heute geht auf die Straße, um zu demonstrieren; Damals «Popper» - heute «Hipster» / At that time «Popper» - today «Hipster»;
- precedent phenomena, known only within the insiders group: В детстве у нас были диафильмы, уличная игра «Казаки - разбойники», черные металлические двуствольные пистолеты и передача «АБВГДейка»/In childhood we had filmstrips, street game "Cossacks - robbers", black metal double-barrel pistols and the television programme called "ABVGDeyka"; Was ist ein Trabi auf einem Berg? Ein Rätsel für die heutige Generation / What is a Trabi on a mountain? A puzzle for the present generation.

It should be noted that the use of such time markers is typical only for the representation of "otherness" in the opposition "young vs. old", which logically follows from the most differentiating criterion: age. The opposition on the basis of sexual orientation is the most ambivalent: in the German press, representatives of the LGBT community are viewed as other, while the tonality of the Russian media discourse, ranging from a sharply negative to a moderately critical assessment of "such people," does not allow us to define them as "others" or as "aliens". Let us provide some examples: И объединяются такие нетрадициональ в ЛГБТ-движения, и начинают на каждом углу выпячивать свои особенности, $и$ требуют к себе внимания/ And such non-traditionalists join in the LGBT movement, and begin to stick out their features at every corner, and demand attention to themselves. And decently nothing comes to mind?; Когдa он произнёс эти слова - «Мама, я гей», сердие моё упало. Я даже в ужасе подумала, что лучше бы самое плохое из моих предположений оказалось правдой / When he said these words - "Mom, I'm gay," my heart sank. I even in horror thought that it would be better the worst of my assumptions turned out to be true; Москве не нужны гейские улииы, как в Манчестере / Moscow does not need gay streets, as in Manchester.

Hierarchy turn. When analysing tactics and techniques for constructing the image of the "other" in the national discourse, it is necessary to emphasize the tradition of monologue in the communicative process of otherness representation. The hierarchy turn allows us to identify a higher position of the representatives of the "own" group in relation to "others." All assessments are made only on behalf of in-group. The particular turn is characterized by the use of metaphors, symbolizing the top and bottom of society: Как не скатиться в черную nропасть инвалидности / How not to fall into the black abyss of disability; Как челябинка помогла колясочнику nодняться с самого дна / How resident of Chelyabinsk helped the wheelchair to rise from the very bottom; die Jungen drängen langsam, aber sicher nach oben.

The disparity between "normal" people, personifying the majority, and all others is verbalized with the help of an indirect comparison in favor of representetives of ingroup: Здесь они, как и многие другие (но здоровые) дети, занимаются в театральной студии / Here they, like many other (but healthy) children, are engaged in a theater studio; Вход воспрещён. Почему детсады не берут в обычные группы детей с инвалидностью? / No entry. Why kindergartens do not admit children with disabilities to the normal groups?; Normale Arbeitsplätze für Menschen mit Behinderung; verbs with subordination semantics: Инвалиды сносили унижения и подчинялись 
нелепому закону отделения / Persons with disabilities suffered humiliation and obeyed the absurd law of sераration; геям остается смириться с неприязнью / gays have to reconcile disfavor.

"Otherness" can be manifested in a carelessly patronizing attitude toward "the other". In the media discourse, predicative elements with an illusory positive evaluation (irony) are used for this purpose: Молодые, амбициозные такие, деятельные! // Чем опасны молодые начальники / Young, such ambitious, active//How dangerous are young chiefs? ; suffixes giving a diminutive-pejorative connotation; dysphemisms: нашлись два... таких своеобразных сапиенса - Владимир Климов из Свердловска и Николай Алексеев из Москвы, которые объявили о проведении гей-парадов в ряде столии субъектов Северного Кавказа / there were two ... such peculiar sapiens - Vladimir Klimov from Sverdlovsk and Nikolay Alekseev from Moscow who announced gay parades in a number of towns in the North Caucasus.

Distancing tactic. This tactic represents "otherness", expressed in the form of a soft conflict discourse and is indicated by the password "I'm not like you". To verbalize the distancing tactic the hybridization turn and the negation of belongingness turn are used.

\section{Hybridization turn}

The hybridization turn is build on the idea of the ethnicity as a social parameter of correlation with others. For modern society, hybrid ethnoidentity is characteristic as a sociocultural construct created, in particular, by the media. Harvard University professor L. Abu-Lughod introduced the term "Halfies" into scientific usage, using it in relation to people whose national or cultural identity is mixed in view of the migration past, other origin or nurture, as a result of long-term studies in another country as well. Under migration, the researcher understands the fundamentally new availability transportation means and communication tools that leads to the formation of socalled "transnational migration" [8]. Citizens of developed countries, inhabitants of megacities, representatives of intercultural diversity in the process of self-identification tend to use a "hyphenated form" by the nomination of ethnicity. The hybridization turn is implemented in the German media discourse by means of the national ethnonyms: Deutsch-Amerikaner (persons having US citizenship, but German origin), DeutschTürken (persons of Turkish origin who hold German citizenship or live in the territory of Germany for a long time), Deutsch-Iraner (Iranian, living in Germany for a long time or having the German citizenship); confessional ethnonyms: Euro-Muslime (European Moslem); ethnonyms which refer to the particular institution: Unions-Bürger (EU citizen). The advantage of "hypheneted form" is the opportunity to combine two or more national and cultural identity into one syntagm without belittling the significance of each component. M. Sher points out that the whole essence of European culture is revealed in the productive rapprochement of antagonistic positions and the complementarity of differences. A researcher regards this manifestation of cultural identity as a special form of representation of ethnic dialogue in the language [9]. However, the lack of a "hyphenated form" of identity consists in the isolation of a smaller social group through its specific nomination from a large ethnic, national community, and in creating the ground for a discourse of hate in the society on the basis of "own vs. alien". In the Russian media discourse ethnonyms consisting of two or more lexical items are also present, as evidenced by the following headlines: $\mathrm{Ha}$ МКС полетят русский киргиз и американский китаеи / The Russian Kirghiz and the American Chinese will fly to the International Space Station (ISS); Русский татарин /Russian Tatar; Российский гастарбайтер прислуживал английской королеве / Russian gastarbeiter served the English queen. Unlike the dominating in the German language, the hyphenated form of writing (bilexeme), the form of the binary substantiveattributive phrase in Russian possesses the transparency of the main and dependent word. In the role of the main constituent of the phrase is usually presented a noun.

The ambivalence of personal identity manifests itself not only at the national macro level, but also at the regional micro level of the nomination, i.e. the degree of particularization of ethnic specifics and differences is increasing. For instance: Türkisch-Neuköllnerin hilft den geflüchteten Frauen, Stuttgarter Grieche zahlt Schmiergeld bei Krankenhausbesuch, Berliner Russen gelten mit ihrem Fleiß und Bildungswillen als MigrationsMusterknaben; Московский таджик покорил СМИ своим благородством / The Moscow-based Tajik subjugated the media with his nobility; Философия дагестанской кухни от московский дагестаниев / Philosophy of Dagestanian cuisine from Moscow Dagestanis; Волгоградские таджики отпразднуют «Hавруз» / Volgograd Tajiks will celebrate Navruz.

In these headlines, the emphasis is placed on the place of residence of immigrants, which is implemented through the use of a hyphen or the addition to an ethnonym an adjective made up from geographical names. In the German media discourse, attention is drawn to ethnonymic units, which are based on the names of the federal states of Germany: Baden-Württembergerin ist die Zweitschönste "Miss Germany» / inhabitant of BadenWüttemberg is the second most beautiful "Miss Germany", Ich bin kein Deutscher, ich bin Bayer / I'm not a German, I'm a Bavarian.

O.M. Hauer-Tyukarkian explains these linguistic facts of territorial identity with the phenomenon of regionalization of the self-perception of German citizens [10]. After all the value attitude to the past is always contextually conditioned, it is the product of social relations; it differs in increasing importance in the modern society. "National" is a sensitive issue for Germany, "being a German" for a long time meant to be responsible for the outbreak of World War II. Identified ethnonyms in the Russian and German media discourses are characterized by a high content capacity and expand our perception of the image formation of a person of another ethno-culture, adapted to living conditions in a new homeland. Using bilexems in German allows minimizing 
the distance between the titular nation and a new citizen of Germany who has a different ethnic origin.

The negation of belongingness turn is based on the desire to dissociate from the "label". To verbalize this turn the following language means are used:

- negative particles "не / nicht" and a negative pronoun kein(e): Mы не старики, старики - не мы / We are not old people, old people are not we; $\mathrm{Mbl}$ не инвалиды, мы как все / We are not disabled, we are like everyone else; Ohne Arme, ohne Beine: ich bin nicht behindert, ich werde behindert!

Denial of stereotyped images witnesses to the unwillingness of "others" to be considered to be a minority: Лучше быть здоровым, чем больным. Лучше быть молодым, чем старым. Лучше быть белым, чем черным. И да: лучше быть гетеросексуальным // Tbl гомосексуалист. Это ненормально. It is better to be healthy than sick. It is better to be young than old. Better to be white than black. And yes: it's better to be heterosexual // You're a homosexual. It is not normal.

A similar trend is observed in media discourses of both countries:

- lexical items особый, особенный / besonderer (special) as regards the "others": Обсуждается вопросы доставки особых людей до шествия, ведь добраться будет не просто, дороги будут перекрыты / The issue of pickup services for special people to the procession are discussed, because all roads will be blocked; B Тотальном диктанте поучаствуют особенные люди / Special people will take part in the national project "Total dictation"; Besondere Menschen-besondere Fahrräder; die Welt der Autisten als ein Kosmos der ganz besonderen Menschen // Geniale Störung: Wir alle sind so anders.

- negation "no": Hem! Mbl не ошибка природы: монологи трансгендеров / No! We are not a mistake of nature: transgender monologues; Nein! ich bin nicht behindert.

The peculiarity of this turn is that narrator's perspective is changing. "Others" deny their belonging to the marginal social group and "insiders" usually prevent the entry of the other in their social network. This concept is confirmed by metaphors with the meaning of duality: Zwischen den Stühlen / fall between two stools; Трансгендер: нахожусь на расnутье / Transgender: I am man in the middle; verbs and participles with the intolerance semantics: мисгендерить / to misgender; ausgrenzen / to exclude, sich distanzieren / to distance oneself, abkoppeln / to separate; вынужденные уехать / enforced leaving.

A distinctive feature of the German society is a more tolerant attitude towards people of non-traditional orientation, as evidenced by the use in the media discourse of predominantly neutral or positively colored vocabulary (in the Russian language euphemisms and peyorativs predominate), as well as a large proportion of publications with statements of famous people about their other sexual orientation, where such "otherness" acquires a positive connotation: Ich bin stolz, schwul zu sein. Ich bin stolz, Republikaner zu sein / I am proud to be a gay. I am proud to be a Republican.
Therefore, within the alteration strategy in the media discourses of both countries, a wide range of language means and stylistic devices is used.

\section{Empathization strategy: comparative analysis in the german and in the russian discourse}

The otherness can be also expressed by means of the empathization strategy, which aims to share someone else's feelings or experiences by imagining what it would be like to be in that person's situation.

\section{Empathization strategy}

The argumentation tactic is used in media discourses in Russia and Germany; it appeals to the nature of otherness with the intention of explaining what are the specific features of the "other". To verbalize the desired meanings allows the communicative turn of "human story" and the turn of statistics.

The "human story" turn is aimed at personalization of information, referring to specific stories from the life of "others" in order to minimise their difference in the eyes of society.

Lexical items история (history), исповедь (confession), Bekenntnis (confession) as part of the headlines prepare addressee for the perception of a new information in a form of confession: Исповедь миниледи, как живут женщины-карлики / Confession of a mini-lady, how do dwarf-women live; eine Geschichte der Behinderten / A story of a disabled person.

The fatic intent of authors of such positive stories can also be expressed in identification statements, which

perform the function of an illustrative example: Nina Waskowski. Musikerin mit Behinderung stellt sich vor I Nina Waskowski. Musician with disability introduces herself; appeals in the form of verbs in the imperative mood: Behinderung: Wer darf leben? Debattieren Sie mit uns! / Disability: who is allowed to live? Let us debate an issue!

The examples below show that the generalizations offered by those who construct the problem can raise doubts, and the stereotypical notions in the society are not always true.

One of the image-making elements of a "disabled person" in the Russian media discourse is its limited mobility, which leads to the inability to broaden the horizons.

In the following example, as a counterargument, the active activity of a disabled person with a diagnosis of cerebral palsy is described: Галя 3. объездила почти всю Европу, побывала во многих городах России, работает, занимается волонтерством и постоянно учится: сейчас заканчивает художественный колледж по специальности художник-прикладник, мастер росписи. Активно увлекается фотографией, мозаикой, иконописью. / Galya Z. traveled throughout Europe, visited many cities of Russia, worked, was a volunteer and is constantly studying. Now she graduates from an art college, specializing in applied art, master of 
painting. She is keen on photography, mosaic, icon painting.

Another consequence of the limited mobility of disabled people is the impossibility to play sports. In the German media discourse we find the following counterargument:

Sport ist mein Lieblingsfach. Mein liebstes Spiel ist Merkball, wo man die anderen mit einem Ball abschießen muss // Behinderung: Was man sich wünscht / Sport is my favorite subject. My favorite game is Merkball, where you have to shoot the others with a ball // Disability: What do you desire?

The potential of turn of statistics is that the numbers and statistical data are considered as an objective information that can convince the addressee in one or another opinion.

The particular turn is implemented by means of the linguistic units denoting "the other," as well as the numbers. For example: По статистике, различные ограничения по здоровью имеют более $120 \mathrm{mblc}$. примориев / According to statistics, various restrictions on health have more than 120 thousand inhabitants of Primorye; По статистике, в России более 12 млн людей с инвалидностью и еще порядка 40 млн маломобильных граждан. Это означает, что практически в каждом московском дворе проживает хотя бы один человек с инвалидностью, просто мы об этом не задумываемся /According to statistics, there are more than 12 million people with disabilities in Russia and about 40 million mobility impaired people. This means that practically every Moscow yard has at least one person with a disability, we just do not think about it.

Compassion tactic. This tactic is built on the objectivization of the emotional and evaluative attitude of communicants to each other, which can manifest itself in a person's ability to recognize the emotional state of the "other", in listening, feeling his / her emotional experiences and expressing willingness to provide support.

Expression of empathy turn:

- lexical items with an emotionally evaluative content of "empathy", primarily evaluative adjectives: Несмотря на инвалидность он милый, симпатичный парень / Despite his disability, he is a nice, handsome guy; Gregor Demblin ist Manager von zwei Unternehmen. Seinen Rollstuhl hat er dabei zum Werbemittel gemacht / Gregor Demblin is the manager of two companies. He has turned his wheelchair into an advertising medium;

- verbs expressing positive feelings and emotions in relation to the addressee: уважать, ценить, восхищаться, achten, respektieren, ehren / to respect, to admire;

- sensory verbs: Besondere Menschen erkennt man nicht, man fühlt sie / You can not recognize special people, you feel them;

- understanding operators: Понимаю, что найти работу сейчас нелегко, тем более инвалиду / I understand that it is not easy for a disabled person to find a job, especially; Homosexualität: Keine Angst, wir verstehen Sie / Homosexuality: do not worry, we understand you;

- association with "others": imagine yourself in the shoes of people in the wheelchair!; Прогулки в темноте.
Незрячий гид водит экскурсии по Петербургу для зрячих / Walks in the dark. A blind guide guides excursions around St. Petersburg for sighted people.

Empathic statements are mostly positively marked their illocutionary force is aimed at supporting the partner in conversation or improving his state of health in order to establish an emotional contact that would allow avoiding difficult communication.

In the Russian and German media discourse there are some metaphors that create the image of "others", in particular the disabled people.

The first metaphorical model represents a disabled person as a hero. The texts emphasize the courage, striking persistence of "such" people and love of life; Дети с синдромом Дауна стали героями великих картин / Children with Down syndrome became heroes of great paintings; Einbeinige Asha Noppeney läuft Marathon; Tanzen trotz. Handicup / Dancing despite handicap.

Another metaphorical model delivers the image of a disabled person as a victim. The pity allows detaching yourself mentally from the situation with the participation of disabled people and putting yourself above "them." Беднье люди: под Волгоградом ограбили семью инвалидов / Poor people: a family of disabled people was robbed near Volgograd; Тяжелая судьба ученогоинвалида / Hard luck of a scientist with a disability; Natalia Wodjanova: Topmodel verteidigt behinderte Schwester / Natalia Wodjanova: Top model defends handicapped sister.

Often, disability is also associated with a heavy burden. Here are some examples of the metaphor: $a$ disabled person is a burden to relatives: Ребенокинвалид-крест для родителей? / Does a disabled child cast a long shadow on its parents?; Behinderung: viele Ehen zerbrechen an Sorgenkindern wie Lotta / Disability: many marriages break up with such troubled children like Lotta.

By creating the image of disabled people, passive structures emphasizing the helplessness predominate.

It must be noted that these metaphorical models are more characteristic for the Russian media discourse. In the German press there were only several cases, which is largely due to the traditions already established in the society in relation to people with disabilities.

\section{Conclusions}

Analysis of the representation of "otherness" in the media discourse of Russia and Germany allowed us to distinguish two main strategies: alteration and empathization. As "others" in the Russian and German media act as representatives of younger / older generation, people who have a non-traditional sexual orientation, disabled people. In the German media discourse, the group of "others" may also include German citizens who have a migration background. The turn of drawing a parallel is common for the Russian and German press, while the hierarchization turn is more presented in the Russian media discourse. Objectivization of "otherness" in the media discourses of both countries takes shape by 
using lexical items within the opposition "we vs. they", comparative constructions, ethnonyms, euphemisms, constructions with a particle not (He /nicht). In the Russian media discourse we have to add to this list metaphors symbolizing the "top" and "bottom" of society and lexical items with suffixes giving a diminutive-pejorative connotation.

Within a framework of the emphatization strategy in the media discourses of both countries, we should highlight the "human story" turn, used as a particular manifestation of the argumentation tactic. Such a way of presentation of "otherness" is relatively new for Russian discourse, but reveals a similar narrative rhetoric with German discourse. The empatization strategy can be articulated by means of positively colored lexical items, numerals, metaphors "invalid equals to hero", "disabled person equals to a victim".

\section{References}

1. E. A. Repina, M. R. Zheltukhina, N. A. Kovaleva, T.G. Popova, C. G. Caselles, XLinguae 11 (2), 557 585 (2018)

2. B. Dubin, Pro et Contra 1(44), 6-19 (2009)

3. G. Ghazaryan, Foreign Languages at Higher Education 1(16), 14-18 (2014).

4. J. Miller, The Journal of Religion 62 (3), 299-304 (1982)

5. R. Scollon, S.W. Scollon, Intercultural communication: A discourse approach (Wiley, Maiden, 2001).

6. M. V. Milovanova, M. Yu. Svinkina, Alienation as foreignization strategy in international and national media discourse in Russia and Germany, ASSEHR 97 (2017)

7. H. Turk, Jahrbuch für Internationale Germanistik 1(22), 8-31 (1990)

8. Abu-Lughod, L. Writing against Culture. Washington, Research Press, (1991)

9. M. Scheer, Bindestrich-Deutsche? Mehrfachzugehörigkeit und Beheimatungspraktiken im Alltag. TVV Verlag, Tübingen, (2014)

10. O.M. Hauer-Tjukarkina, Politia 4(71), 67-78, (2013) 